\title{
MODES OF PERSUASION IN THE SERMONS OF FATHER PROFESSOR CONSTANTIN GALERIU
}

\author{
Ph.D. Andrei Emanuel RADU, \\ Faculty of Orthodox Theology, \\ Babeș-Bolyai University of Cluj-Napoca, \\ ROMANIA, \\ E-mail: radu_andrei_emanuel@yahoo.com
}

\begin{abstract}
Father Professor Constantin Galeriu is one of the outstanding figures of the Romanian Orthodox Church, mainly due to his fervent preaching activity, but also due to his oratorical talent evident in his sermons and catecheses. His homiletic work, of such impressive extent, offers the reader rich study material from which to extract teachings that prove useful in everyday activity, but especially in the pursuit of immortality. An extremely cultured man, concerned with the study of philosophy, medicine, psychology, Father Galeriu proposed a new comprehensive approach to these domains in the light of theology, directing man to the source of creation - God. In his sermons we can easily identify the sources the author compiled, such as the Holy Scripture, the writings of the Holy Fathers, treaties of philosophy, ethics, psychology etc. They all provide solid grounds to the sermon, but also ensure the accurate understanding of the message that the preacher wishes to convey, in all its complexity. Moreover, the spiritual condition of Father Galeriu as well as the knowledge he acquired through incessant study contributed to the development of certain sermon topics such as salvation, love, faith, family, all rooted in the text of the Holy Scripture. The message of the sermon is profoundly Christian and always topical and relevant - in the light of the new research and discoveries, because it relates to God and to the crown of creationMan, a dynamic being always in search of truth and perfection. This desire of man, to attain fulfillment through God, to aspire towards likeness to the Creator (Gen. 1,26) is addressed by Father Galeriu, as that it is the only way man can remain an active member of Christ's Church.
\end{abstract}

Keywords: Father Constantin Galeriu; sermon; homiletic sources and topics; the Holy Scripture; sin; atheism; selfishness;

\section{PRELIMINARY REMARKS}

The sermon is a type of discourse delivered in the ecclesiastic environment, conveying religious and moral teachings useful to those who find themselves on the pathway to perfection. It is not meant merely to convince the audience of certain truths, but also to make such truths be followed and fulfilled. In order to achieve this goal, the preacher must prepare and present a speech of well-grounded theological content, and this becomes possibly using sources characteristic for this type of discourse. The originality of a sermon will lie in the manner in which the preacher elaborates on the contents, the entire material being processed and conveyed in a coherent form. Thus, in preparing the sermon, "the Christian orator uses various sources: the Holy Scripture, books of sermons, textbooks, 
liturgical books, specialized research etc. Yet, in the sermon he is putting together the priest must show what makes him unique, he must leave the mark of his particular style. All his thoughts shall be filtered through his mind and ideas will then be ordered in writing"'.

\section{SOURCES OF THE SERMON}

The sermons of Father Constantin Galeriu are speeches of outstanding homiletic value, "the contents of the Father's preaches, based on the Holy Scriptures, the Holy Fathers, the meditations of the greatest philosophers of the world, and to no lesser extent, his own clerical feelings and experiences, were presented in a refined liturgical language, in harmony with an adequate personal style, and, additionally, with discreet gestures and a facial expression that emphasized the truths he was preaching". The first part of the study presents the main homiletic sources identifiable throughout his speeches. By using such sources the author attempts to present the Gospel message in well-designed form, firmly supported by arguments. Father Constantin Galeriu was one the few who built bridges between theology and sciences such as philosophy, medicine, psychology, sociology, physics etc, showing that there has never truly been any contradiction between them, but rather, that these sciences have found their true meaning in light of theology. We note that the Father's sermons include references to various personalities that worked in different fields and who were in search of the truth but who placed their search in ongoing dialogue with theology. This characteristic of the sermons of Father Galeriu is, as we will see further on, a consequence of the fact that the Holy Scripture and the writings of the Holy Fathers are thoroughly known by the author, whose theological culture does not allow for any dogmatic errors. These considerations will be substantiated by presenting the main sources that Father Galeriu uses in writing his sermons:

\section{The Holy Scripture}

Whatever type of sermon Father Galeriu delivered, be it moral, historical, dogmatic, or apologetic, he turned to the Holy Scripture as the main homiletic source in producing his work. The scriptural text's profound significance needs to be explained and for this reason the sermon can be considered an extension of the Gospel. That the sacred text is well known by the preacher can be seen from the impressive number of verses encountered in its contents. The speeches show that the comprehension of the text is attained in an authentic manner, according to the teachings of the Church, and this is due to the fact that Father Galeriu lived for the Word, was pervaded by it, because the Savior's words are "spirit and life" (John 6,63$)$. We shall present here a fragment which quotes, in a completely logical sequence, texts from the New and Old Testament, as well as explanations to the point required in order to understand these texts:

"The soil, the oxen, the woman, in other words: the earth, the creatures, our human family. Again, some words: the entire world. Was the Creator ignoring this world, His own world? «Through Him all things were made» (John 1, 3). And all that He loves. He names the earth «His footstool» (Matthew 5, 35). "The ox and the donkey warm his body in the cave of the Nativity», because in their stable they have recognized their Master (Isaiah 1, 3). And also, He, the Son of God Himself is born from the womb of a woman, He blesses the wedding, He loves the family: "And Jesus loved Martha and her sister and Lazarus» (John 11, 5). Therefore, all these - the soil, the oxen, the woman, he holds in His divine care and love. But, above all, as the Scripture states, they, the

\footnotetext{
${ }^{1}$ Pr. Vasile Gordon, Pr. Adrian Ivan, Pr. Nicuşor Beldiman, Homiletics, Ed. Basilica, Bucharest, 2015, p. 467.

2 Pr. Nicuşor Beldiman, „The Homiletic Activity of Father Prof. Constantin Galeriu (Ph.D.)” în Teologia, 1 (2018), p. 73.
} 
creatures, are God's gifts to man - «to rule... over all creatures..., over the entire world» and «taste of all the fruit trees of the Paradise», as He commands Adam. All I have given to you, He tells Noah. Adam knows that even Eve, his woman, is a gift to him, and for that he speaks to the Creator: «The woman you have given me...» (Genesis 3, 12). God says that His very Son is a gift offered to us: «God so loved the world that He gave His Only Begotten Son, so that whosoever believes in Him shall have eternal life...» (John 3, 16)",3.

\section{Patristic Theology}

The genuine knowledge of the text of the Holy Scripture is based on in-depth study of patristic literature. A hard-working preacher will seek that his interpretation of the scriptural fragments be one in the spirit of the Church Fathers. The risk of putting forth a personal exegesis, which is not anchored in the tradition of the Church, may have serious consequences, and this is easily noticed in the neo-Protestant milieus. Father Galeriu mentions the Fathers of the Church such as Saint Gregory the Theologian, Saint Basil the Great, Saint John Chrysostom, Maximus the Confessor, Saint Isaac the Syrian and others. When speaking to the Christians about man's soul, he presents before them the reflections of those who were enlightened by God to decipher the depths of man:

"Oh, Lord, how wonderfully Saint Maximus the Confessor explains the mystery of the soul! Let's understand now. And by understanding part of the mystery of the soul, let's raise to the superior level and understand some of God's mystery. Saint Maximus the Confessor says: «Our soul is simple, one and indivisible; but it finds itself in a body made up of so many parts». Therefore, the soul is indivisible in a divisible body. The second quality of the soul: our soul, infinite, dwells in a body inhabiting one particular place; but the soul spreads its wings beyond that. Let's allow ourselves to feel, because then we will understand. And the third quality of the soul: it is moved by someone towards a purpose, a goal. What is the goal? Oh, Lord, after Saint Maximus, Father Calist so beautifully puts it: «God gives us movement!». But movement differs with each creature. The stars move in a certain way, for example; they move according to a certain order; living creatures move in a different way... What about man? Does the movement of man's mind ever stop anywhere? Then, as Father Calist says, it is certainly mad to move endlessly (to reach the margins of the world and beyond). Because my soul is caused by Somebody to move endlessly, to move towards Him for it was made in His image" 4 .

Also, speaking about the people's cooperation with Holy Spirit, he said:

"That's why our Saviour say: «Receive the Holy Spirit; If you forgive anyone's sins, their sins are forgiven...». And listen to Saint Cyril of Jerusalem, how beautifully he says this: «Because the first breath was darkened by the voluntary sinning, only God with His grace, with the divine eternal light could once again restore the being». Referring to the same moment, let us hear the wonderful words uttered by Saint Gregory: «Creation becomes new once more when it shares in the Spirit, the absence of which made it old. For we need to work with the new from the beginning»"s.

\section{Christian worship}

Prayers, chants and liturgical texts are elements that can be integrated in the contents of sermons. Living in a liturgical atmosphere where God is an intimate presence within each one of us, will contribute to the making of a live sermon, impregnated with spirit. Father Galeriu was a man of the Church who devoted his life to serving the Holy Altar, and his preaching is the expression of this way of life. Quite often he would insert in his speeches excerpts of liturgical texts, thus demonstrating showing the unity between liturgy and

\footnotetext{
${ }^{3}$ Pr. Constantin Galeriu, „Predică la Duminica a XXVIII-a după Rusalii” (Sermon on the 28rd Sunday following Pentecost), Glasul Bisericii [Voice of the Church], 10-12 (1977), p. 831.

4 Pr. Constantin Galeriu, „Predică la Duminica Femeii Samarinence” (Sermon on the Sunday of SamaritanWoman), în 10 predici de părintele Galeriu la 10 ani de la mutarea sa la cer (10 sermons by Father Galeriu,marking 10 years from his passing), Ed. Lumea Credinţei, Bucharest, 2013, pp. 65-66.

5 Pr. Constantin Galeriu, „Predică la Duminica Sfântului Apostol Toma” (Sermon on the Sunday of the Holy Apostle Thomas), în 10 predici de părintele..., p. 45.
} 
sermon, while at the same time using this as an opportunity to explain the word of the Gospel. As an example we quote extracts from a speech delivered by Father Galeriu on Saint Thomas's Sunday:

"Eight days later, the disciples were once again gathered... now Thomas was with them. And Jesus came. With the doors locked, He stood amidst them and said: «Peace be with you!» Then he addressed the man that had doubted him: «Thomas, put out your finger, and see My hands; reach out your hand, put it into My side. And be no longer in doubt, but believe». The Church so enlighteningly tells us: «Thomas, who was also named the Twin, was not with them when you entered, Christ, through the locked doors, and for this and because he did not believe what they had told him, You turned his disbelief into belief and, oh, my Good Lord, You did not consider it demeaning to show him Your pure side and the wounds in Your hand and Your feet. And he, upon touching and seeing them, confessed that You are not only God and not only Man and exclaimed: «My Lord and my God!»»" .

When reminding us of the fact that prayer must accompany us at all time, Father Galeriu shows that the offices of the Church hours are occasion for us to share in the grace of the Holy Spirit, just as the text of the hymns says, for,

"You begin your day by sanctifying it with Our Father, then from the Horologion - the richest book of prayers an Orthodox Christian has - you read the Hours, ordered in a certain way, to mark our time, wherever we are. Because the texts of the Hours - the first, the third, the sixth, the ninth - are hymns referring to the life of our Savior, my beloved brethren. At the first hour: «In the morning, my Lord and God, hear my voice». At the third hour, what event took place? The descent of the Holy Spirit on the Pentecost. And there is the hymn: «Oh, Lord, You have sent your Holy Spirit to your apostles at the third hour, do not take Him, my Good Lord, from us, but renew Him in those of us who pray to You». The sixth hour, as we read in the Horologion: «You, the One who in the sixth hour on the Cross nailed the sin boldly committed by Adam in Heaven and abolished our errors, O Jesus Christ, our Lord, redeem us». Here we comprehend that our Savior, being nailed onto the Cross as You were, abolished our errors, our curse. And at the ninth hour, three in the afternoon: «You who at the ninth hour for us tasted death in Your body, kill our bodily conscience, oh Christ, our Lord and save us». In other words, at any time during the course of a day, wherever you may be, think and pray" ${ }^{\text {" }}$.

\section{Devotional Literature}

Devotional writings are a highly useful source in preaching the Gospel. With their aid the preacher can address the intellect and the spirit at the same time, awakening deep insights in each and every believer. By presenting various stories, events, testimonies of the saints, the believer is provided with examples of virtue that he has the obligation to follow in his spiritual ascent. By preaching about grace and the fact that the Spirit is present where there is holiness, Father Galeriu narrates an episode of the Paterikon, highlighting its significance:

"Once a year a disciple would come to Saint Anthony ... Many others would ask him: «Father, tell me the answer to this or that question!». But this disciple never asked him anything. He simply sat by him. «Do you have nothing to ask me, nothing to say to me?», and the man answered: «Father, sitting by your side is enough for me». He felt the presence of grace, of light, of holy peace. That's how the saints were. One prayed to God: «O, Lord, give me the strength to take upon me the disease of this leper, and may he receive my health». What a state of grace!... Imagine someone, for example a person suffering from AIDS nowadays, receiving this state a grace from a doctor. In

\footnotetext{
${ }^{6}$ Ibidem, p. 47.

${ }^{7}$ Părintele Constantin Galeriu, „Predică la Duminica a XXVII-a după Rusalii” (Sermon on the $27^{\text {th }}$ Sunday after Pentecost) http://www.crestinortodox.ro/sarbatori/duminica-27-dupa-rusalii/tamaduirea-femeii-garbove98087.html, 12.06.2017.
} 
other words, imagine how would it be for someone to share in the peace of God that exists inside you, because this is what our Savior desires"8.

When preaching about the virtue of faith, he brings forth as a testimony the pure life of Saint Maximus the Confessor who was persecuted because of the tenacity with which he defended the Orthodox faith:

"Faith transformed the law of your nature from corruption to incorruption... This is where the law of God's nature intervenes, the power of God, and, as Saint Maximus said, faith turns the law of nature into the law of God, the Creator, the All Powerful, but only once you have freed yourself from all that weakens you and all that makes you doubt. Only when I read these profound thoughts did I realize. This man, Saint Maximus actually experienced this: the soul transcended the afflictions of the body. Trials, tribulations, suffering... For the sake of his faith you know how far he went. The emperor himself opposed it. But he never wavered. And in order to stop him from speaking and writing, he was threatened: «If you cling to your belief, which you claim to be the truth, you shall suffer the following punishment: your tongue will be torn out and your right hand will be cut off». Saint Gregory the Theologian, whom he knew by heart, had said: «The Lord asks for the truth from the tongue, the faith from the soul and the restraint from the body». He was given the choice to be silent, to stop bearing witness to the truth or to maintain this testimony. And his right hand was cut off, and his tongue was torn so that he would stop preaching. But his faith remained in the godly light",

\section{Church History}

The speeches of Father Galeriu present events from the History of the Church. The teachings of the Church were established over the centuries by those who served it, guided by the grace of the Holy Spirit. Father Galeriu, guided by the same grace, often refers to the important moments of the history of the Church and to the teachings established during such moments, thus showing that his sermon is consistent with the truth of the Gospel, defended and sacredly preached by the Holy Fathers. In this respect, we present an excerpt referring to the reasons for the assembly of the Ecumenical Councils and the importance of the dogma defined at such assemblies:

"We know how Arius opposed the confession that Jesus Christ is the Son of God, born from the Father, not made, one with the Father, true God and true man. And, following the confession at Nicaea in 325 (under the rule of Constantine the Great), the first part of the Creed, up to the verses containing the confession of the Holy Spirit, while in 381, at the second Council (during the reign of Theodosius the Great), the second part of the Creed was formulated: "And in the spirit of the Holy Spirit, the Lord, maker of life, who from the Father proceeds...», as we all confess. Then, in 431, the Council of Ephesus convened, where it was confessed that: the Son of God descended from heaven and was incarnate from the Holy Spirit and from the Virgin Mary. And where did this union occur, His Incarnation from the Holy Spirit and the Virgin Mary, His assuming of a body? In the Virgin's bosom. Let us cherish, as we would a sacred gift, this idea because some Christians - in their own way, being separated from the Church - do not understand how the Mother of God is truly the Theotokos, the bearer of God. For where did this union between God and humanity take place? In the bosom of the Mother of God. She gave birth to God-the Man. We can understand the truth and logic that lie in this fact. Therefore, in Ephesus, the belief in the Mother of God was confirmed. But it was in Ephesus also that misunderstandings occurred. How could God and humanity, the divine and the earthly be united in the bosom of the Virgin? Two sides were formed: one of them, according to the School of Antioch, believed that in Christ there are two natures, both divine and human, which are joined by will, or as they said, morally. In which sense?

\footnotetext{
${ }^{8}$ Părintele Constantin Galeriu, „Predică la Duminica a XIX-a după Rusalii” (Semon on the $19^{\text {th }}$ Sunday after Pentecost) http://www.crestinortodox.ro/sarbatori/duminica-19-dupa-rusalii/predica-pe-munte-iubireavrajmasilor-96932.html, 12.06.2017.

${ }^{9}$ Părintele Constantin Galeriu, ,Predică la Duminica a XVII-a după Rusalii”” (Sermon on the $17^{\text {th }}$ Sunday after Pentecost) http://www.crestinortodox.ro/predici/predici-duminica/duminica-femeii-cananeence-123259.html , 12.06.2017.
} 
Particularly Nestorius, who became patriarch of Constantinople, said: They are united but morally; the man in Christ, with His human nature, cleansed from the evil, suffered on the cross as man. Because of this they opposed the tenet of the Virgin as Mother of God... The sister of the emperor, Pulcheria, a very religious woman, mentioned also in the calendar, was married to the leader of the army - Marcian, a general, of course. And both believers decided the assembly of the Council in Chalcedon, in 451.630 bishops gathered - the greatest assembly of bishops in those times in the world. They prayed and reached an understanding. The assembly was held in Chalcedon in the Saint Euphemia Church... And they said: «Following the Holy Fathers, we all teach and confess to the One and Same Son, our Lord, Jesus Christ, perfect in His godliness and perfect in His humanity, true God and true man, having a rational soul and body, the same nature as the Father, according to His divinity, and the same nature as us according to His humanity, being entirely like us, with the exception of sin. Because the Lord was begotten before all ages from the Father, according to His divinity, and as a man He was born in our days and for our salvation from the Virgin Mary, Mother of God - Theotokos, One and the same Christ, Son, Lord, Only-Begotten, known to possess the divine and the human natures, unconfused and unchanged and undivided and unseparated, the difference between the natures not being destroyed by their union, preserving in particular the characteristics of each and joining together in the same individual and in a single state, not in two people, divided or separated, but One and the Same Son, Only-Begotten, God-the Word, the Lord Jesus Christ. This is what we learned about Him from the prophets and our Lord Jesus Christ Himself so conveyed to us, the Symbol of the faith of our parents $» " 10$.

\section{Lay Literature}

The theological and lay culture of Father Galeriu was one of the reasons why his sermons were followed with great interest not only by those drawn to oratorical talent, to his devotion and gentleness, but also by those who found in sermon a source of information and knowledge. The great amount of information, from various domains - literature, art, philosophy, physics, medicine, etc., is given accessible and coherent form, theologically and scientifically. Being concerned with the research conducted in these fields, by referring to the writings of scientists, poets, philosophers, he shows that between theology and science there is an indissoluble relation. In this respect, when speaking about the order imposed by God in creation, he quotes a great Romanian physiologist, Nicolae Paulescu, whose pure life and research work dedicated to man and God, he highlighted on every occasion:

"Beloved, this man - and it is an example - attained the truth by means of an enlightened reason, revealing the truth to his fellow people with his mind, but at the same time by keeping himself pure, virgin, in virginity. Just as the Mother of God is a virgin and a mother. Only in chastity and maternity the truth is fulfilled. How can that be: by preserving her pure being, not defiled by the rottenness of the world. In the mud of passions, how can the truth be visible? It is only in the pure soul, the chaste heart and the mind in search of truth can one reach the truth. This was Paulescu. This is how he came to the truth, so that, by knowing the truth of man with a mind enlightened by God, as a physiologist, he came to know the human being in its morphology and in its physiology. For each organ, each tissue, each cell, each element in our being, has a superior purpose. There is harmony, there is an entirety. This harmony is not placed by me. When I come to the world, I am already created. Another has created this harmony - God. He placed harmony in the entire being, a conscience in man, and for this reason Paulescu says that the soul of man is the agent of purpose. That is, my spirit, enlightened by God, perceives this order, ascends to God and, by ascending to God my soul enlightened by the divine light, by divine love, by faith in truth... my thinking ascends and creates me. This wonderful artist, as Paulescu says it, which is the soul of man, at the

${ }^{10}$ Pr. Constantin Galeriu, „Predică la Duminica a VI-a după Rusalii” (Sermon on the $6^{\text {th }}$ Sunday after Pentecost),

http://www.crestinortodox.ro/predici/predici-duminica/vindecarea-slabanogului-capernaum-96267.html, 
same time creates my body. And my being starts, from the point of its source, as it was created by God, on the path to perfection, to resemble God""

He often recited from memory verses that he inserted in the sermon, showing the depth of the poet who, with his mind, comprehended Christ's mind (Philippians 2, 5):

"God prepared the kingdom before we came into the world, it is God's gift. And we are its heirs. $\mathrm{He}$ is the Beginning and the End. The prophet Isaiah says: This is what the Lord says: I am the First and the Last and there is no God other than Me. I am Alfa and Omega, the beginning and the end. Coșbuc also expresses his musings, in the spirit of the Scripture: Tu tot ce-ți pui in gând e numai vis,/ Căci Dumnezeu te poartă-n voia Lui (All that you have in mind is but a dream/ Because God drives you according to His will). In our being there is aspiration, there is desire, but God carries you according to His will. He is also your Creator and the goal towards which you direct your life" ${ }^{\prime 2}$.

\section{MAJOR THEMES OF THE SERMON}

Father Constantin Galeriu stood out within the Church as an exceptional preacher and a scholarly theologian. His style in preparing and delivering speeches will constitute a model to be followed by those who are concerned with the preaching of the word. A sermon, no matter how well delivered, remains a fruitless oratorical undertaking if it is not filled with equally superior contents. The speeches of the reverend Father are characteristically rich, conveying a profound message to the audience; this is owed to the fact that they originate in the pure soul of the author, who constantly tapped into the ever flowing source of the Gospel.

In the sermon, the reverend Father tackles topics that concern each and every single Christian, contemporary issues referring to spiritual life, family life, living in society etc. The manner in which certain concepts and teachings are presented, so as to be understood also by those who do not possess extensive theological knowledge, portrays him as an experienced teacher who manages to awaken in every person the conscience otherwise muted by passions. In addition to themes that are normally debated within any sermon: salvation, good deeds, love, faith, sin, virtue, the father professor focuses on issues that involve knowledge from various fields, such as philosophy, ethics, ecclesiology, medicine, psychology etc.

Father Galeriu's interest in studying is revealed by the complexity of the contents of his sermons. His views were always fresh and original, seeking to enlighten the listeners and convince them of the truth preached by the Gospel. Although he spoke before a heterogeneous audience, comprising both simple and educated people, his word was one, persuasive in its simplicity and coherence, and it addressed everybody. By offering answers supported by arguments to the various questions that arose in the minds of his listeners, the sermons of the Father were occasions for meditation and accumulation of new knowledge. We will present some of the important themes encountered in the sermons of the reverend Father, with a view to showing the depth and originality of his thinking.

\section{God's Existence}

Often Father Galeriu was concerned with complex topics, which required explanations well supported by arguments, such as that of the existence of God. A spiritual

\footnotetext{
${ }^{11}$ Părintele Constantin Galeriu, „Predică la Duminica dinaintea Înălțării Sfintei Cruci” (Sermon on the Sunday beforethe Exaltation of the Holy Cross) http://www.agoracrestina.ro/biblioteca/constantin_galeriu_1918predica-la-duminica-dinaintea-inaltarii-sfintei-cruci.html, 27. 07. 2017.

12 Pr. Constantin Galeriu, „Predică la Duminica a XII-a după Rusalii” (Sermon on the $12^{\text {th }}$ Sunday after Pentecost), în 10 predici de părintele..., p. 103.
} 
comprehension of the world and of the purpose for which it has been created, namely to fulfill itself in God, made Father Galeriu assert that our attempt to certify the Creator's existence is a nonsense. What should drive us is another type of knowledge, not of intellectual nature but of spiritual nature; not by attempting to comprise God conceptually, with scientific arguments, but by means of faith. Christians have overcome the state of uncertainty and now seek union with God, not at conceptual level, through intellectual arguments, but personally, by spiritual feeling:

"For the believers - especially for us, Easterners -, the great problem, my beloved, is not the existence of God. Because only the foolish man- poor soul, can deny the existence of God, which is so utterly obvious. I truly lament this, because I pity the foolish man. But in the West this problem is raised, unfortunately. But what do I mean? The problem for the believer is not this. God exists whether or not I give him a Certificate of Existence - in the Fundamental Theology course that I am teaching I have ceased to raise the problem of rational arguments supporting the existence of God. All that is alive and living is a testimony to God. So, in our case, this is not an issue, God exists! The other problem of great depth for us is the one that refers to my relationship with God. This is the true problem: how I stand before God; how I feel God"13.

Man's communion with God is what convinces us of this truth, because, through faith, we feel how Christ is more and more present in our life, as the Holy Apostle Paul says: "I no longer live, but Christ lives in me" (Galatians 2, 20). Father Galeriu warns of the risk entailed by the stance we take before God, as a consequence of our freedom, for "all that is important is how I stand before God and not how God stands before me. Let us retain this idea: God exists, but how do I stand before Him? I can be open or reject Him; my freedom, the freedom that God gave me, sometimes makes me withdraw"14.

\section{Atheism - an avatar of passions}

Faith in God eliminates any doubt regarding His existence. The Holy Apostle Paul defined faith as "the substance of things hoped for, assurance of things not seen" (Hebrews 11, 1). Atheism is a decisive refusal of some people to believe in the True God - the guarantor of freedom (II Corinthians 3,17 ), and becomes a way of living in which the man finds a fake freedom and delusive happiness in passions:

"Most often someone is said - or he declares himself - to be an atheist. There are no atheists! Such a man rebels against God the Living and the True, but makes other gods for himself. He creates a kind of happiness of this world. Or an idol of this world: a pleasure, a passion. This is how idols were created, from this rebellion and original fall. But the idol you build for yourself is no longer God, it is from this world and will bury you in this world. This is something all atheists should know. They are not Godless, they deify something else. And what they deify are whitewashed graves" $" 15$.

Father Galeriu shows that through atheism one separates oneself from God, but not from gods, and these gods are the passions, more precisely, they are man's attempt to detach himself from God's eternity and to join the temporality of the immanence. Man is thus isolated, not only in space but in time, everything is contained in this hic et nunc. Overcoming this state is possible by following the reverse path, and Father Galeriu shows

\footnotetext{
${ }^{13}$ Pr. Constantin Galeriu, „Predică la Duminica a VIII-a după Rusalii” (Sermon on the $8^{\text {th }}$ Sunday after Pentecost)http://vremurivechisinoi.blogspot.ro/2013/08/predica-la-duminica-viii-dupa-rusalii.html, 12.06. 2017.

14 Ibidem.

15 Pr. Constantin Galeriu, „Predică la Duminica a X-a după Rusalii” (Sermon on the $10^{\text {th }}$ Sunday after Pentecost)http://www.crestinortodox.ro/sarbatori/duminica-10-dupa-rusalii/vindecarea-lunaticului-96535.html, 12. 06. 2017.
} 
that man must seek virtue in order to re-enter the eternity offered by the communion with God:

"The virtues, as the Holy Fathers say, are older than us, because they are godly qualities. That is why we confess light, the divine grace, uncreated and eternal. And you, the transient being, share in God's eternity. This is the beauty of the soul. Reflect on it, my beloved! It beautifies you at any age, because it comes from eternity, it is timeless, ageless... If we wish for beauty, let us share in the holy gifts of the divine virtues, which recreate in us the image by which we were made - of Christ the Savior" $"$.

\section{Selfishness, the cause of the original sin}

As the Holy Scripture tells us, the sin of our ancestral parents, Adam and Eve, originated in their wish to be like God, knowing good and evil (Genesis 3, 5). This implies that man should forsake his own condition, that of created being. Man, at the snake's suggestion, closed himself to the world, attempting to become a center, like God, to become independent, to impose his own laws onto creation. Thus, man, by this attempt, creates a rupture, a gap between himself and God. Father Galeriu explains the words of patriarch Abraham (Luke 16, 26) as referring to this condition of man:

"«Between us and you a great chasm has been set in place, so that those who want to pass from one side to another, cannot». What is it with this chasm? It is explained by the Holy Fathers, particularly by Saint Maximus the Confessor: It is the gap so deeply dug by my selfishness, by my self-worship and by the worshipping of earthly, ephemeral goods which become my grave unless I transform them into my path to eternity. For the gap between the unhappy rich man and Lazarus in the bosom of Abraham is not as great as the gap existing between us and God, due to the lack of love, by closing oneself as in a grave. The Fathers testify to it and we continually repeat it: the sinner does not fall from the arms of God, but closes himself as in a grave. This is the gap that only love and divine light can abolish. These two can abolish the chasm" $"$.

Once they committed the sin, Adam and Eve were faced with its effects, because they were naked (Genesis 3, 7), for, though they became gods for themselves, they did not become like God. They experienced failure, disillusionment. Through sin, the two became guiding principles and began to organize their life according to their own laws, with no God, but aware of their status as limited creatures. The words of Father Galeriu describe this state of uncertainty of the first people:

"What does sin, in its working, in its appearance, consist of? Sin, as Scripture reveals it, making it clear for everyone, is instilled (not inspired - only God inspires us) by the devil, who put on the form of the snake, telling Eve: «Has God told you that should you taste the fruits of the tree of good and evil you will die? No, you will not die, but you will be like gods, knowing good and bad». This is the picture and a kind of beginning of the sin: You shall be like gods; you will be gods (written in the plural in the Scripture; that is why idols appeared), knowing good and evil you will decide what is good and what is evil. Let us consider this for a moment: like gods. You shall become your own God ... In God's place you are tempted to make a new start, therefore. On another occasion we explained pride. When Lucifer wanted to place his throne next to the Almighty, he, Lucifer, the bearer of light, next to the Almighty, and the prophet says: Oh, how low you have fallen, Lucifer!, and our Savior saw him fall, as we find in the Holy Gospel of Luke: «I saw Satan fall like lightning from heaven». God enlightened us on how to explain the sin of pride,

\footnotetext{
${ }^{16}$ Pr. Constantin Galeriu, „Predică la Duminica a XXIII-a după Rusalii” (Sermon on the $23^{\text {rd }}$ Sunday after Pentecost)http://www.crestinortodox.ro/sarbatori/duminica-23-dupa-rusalii/vindecarea-demonizatului-tinutulgherghesenilor-97100.html, 12. 06. 2017.

${ }^{17}$ Pr. Constantin Galeriu, „Predică la Duminica a XXII-a după Rusalii” (Sermon on the $22^{\text {nd }}$ Sunday after Pentecost) http://www.crestinortodox.ro/sarbatori/duminica-22-dupa-rusalii/bogatul-nemilostiv-saracul-lazar97225.html, 12.06. 2017.
} 
which is caused by our attempt to place the beginning of everything in ourselves. But understand, once and for all that you are not your beginning: There was a time when you did not exist" ${ }^{\text {. }}$

Once he became aware of his condition, man looked to his Creator, to the principle of his existence. The incarnation of our Savior Christ opened the path to a new ontology, and man has to preserve this relationship with God. The new man, created in Christ, has overcome selfishness, and has found the sense of his existence in the Creator. The Savior's words "You can do nothing without me" (John 15, 5) shows this limitation of ours, and Father Galeriu insists on this, showing man's impossibility to live independently of his Creator and find happiness in this limited world:

"You cannot save yourself by your own powers; you have come from non-being and became a being. He continues with strong and profound words: «What will it profit a man if he gains the whole world yet forfeit his soul? Or what could anyone give in exchange for their soul?». More words of great wisdom! The soul, together with the body in which it lives, as a kind of dwelling place of the soul. The soul is united with the body, but is not one with it. It is united and different at the same time. Oh, the mystery of the soul! And I constantly carry this grief, that I confess: We do not experience enough of the mystery of our soul, that is why we don't really feel its truth in its depth, its reality. We live contemplating our body for too long, and so we have come to say that matter is everything. And the poor people say it without thinking that nothing would have been created without the soul, without thought. That is why we come to be so brutish, like beasts, because we have no consideration for the soul. Nothing is created without the soul, without thought, which is the fruit of the soul. Everything is thought. Any creature is a masterpiece, it is the idea of the Creator"19.

\section{Prayer}

In order to regain the communion he had enjoyed prior to sinning, man must resume his dialogue with his Creator. Prayer is a means of conversing with God, certainty based on faith being a mandatory condition. God made us eternal dialogue partners, and through our prayers we have a foretaste of eternity. The exhortation of the Holy Apostle Paul: "Pray incessantly" (1 Thessalonians 5,17$)$ means that we open to God, it entails a desire that we need to act on, every day. Father Galeriu, whose life became a living and continuous prayer to God, confessed to believers:

"When you pray you feel that you have passed to the other side, crucifying this world. «The world is crucified and I am crucified to the world» (Galatians 6,14), says Paul. This means the world of limitation, of death. In prayer you feel you have passed beyond the threshold, beyond the world of death, because you are praying to the living God. And by uttering each word of prayer, with holy strength, focusing your mind on every word of the prayer and reflecting, you have passed over the threshold into the world of Divinity, into the world of omnipresence and eternity of God; and when you receive communion, you have a foretaste of the Resurrection. If the law of sin has kept you here, in the limited world, then the law of God, the logic of God will raise you to God's eternal today given to you as a preliminary glimpse of the Resurrection. This was given to the disciples on Mount Tabor and it is given to anyone who is holy, here, in this world. We felt and we confessed; let us each experience this: when you are baptized, when you pray, when you read the Gospel, when you confess, when you share and strongly believe, as you do in the morning, you open the room where you sleep and all of a sudden fresh air comes in, in its freedom: so does the Holy Spirit embrace the entire heaven ... As you pray: «Oh, Heavenly King, Comforter, the Spirit of Truth, you who are everywhere present and fills all things, come and dwell unto us, and cleanse us of all impurity, and save our souls!». By strongly saying this and opening the window of your heart through faith, then, just as the fresh air enters the room so does the Holy Spirit, the grace of

\footnotetext{
${ }^{18}$ Pr. Constantin Galeriu, „Predică la Duminica după Înălțarea Sfintei Cruci” (Sermon on the Sunday after the Exaltation of the Holy Cross)

http://www.crestinortodox.ro/predici/predici-duminica/luarea-crucii-urmarea-hristos-96804.html, 12.06.2017.

${ }^{19}$ Pr. Constantin Galeriu, „Predică la Duminica după Înălțarea Sfintei Cruci” (Sermon on the Sunday after the Exaltation of the Holy Cross)...
} 
God, the divine light and you feel invigorated, resurrected. Then you come to believe just as the saints believed",20.

\section{Life and death}

Man can perfect himself and he owes this possibility to the Sacrifice and Resurrection of our Savior Christ, who opened the path to salvation for us. Through the Holy Baptism man is born to a new life, which is a preliminary stage of eternal life. The man who is engaged in this dynamism imprinted through the act of creation, of gaining likeness to God (Genesis 1, 26), will attempt to exceed the biological level of living, choosing to care for his soul and to cleanse it. It is in this sense that life must be understood. Father Galeriu showed that our purpose is to practice virtue in order to attain it: "Sharing in God's grace opens for us the path to a new life, but it must not be understood as the mere existence of the individual:

"When we say life, we feel in this word our own life. But not life in the biological sense, or in the zoological sense, not this simple life is sought, but rather eternal life, everlasting life, God's life. And we feel the longing, the aspiration to the life beyond this earthly life, spanning just a number of decades. This life is in us, and nobody, should he think logically, will be able to deny it because the thirst for full, true, immortal life, the thirst for truth is structural to our calling, to our vocation" ${ }^{\prime 21}$.

By incorrectly relating to life and to its significance, man will come to misunderstand death. The conception of biological death as a transformation into a nonbeing cannot be accepted by Christianity. Death is the end of life on earth, but at the same time it is its extension, a continuation of our dialogue with God. Father Galeriu illustrates that the novelty which Death and the Lord's Resurrection contributed to creation consists of killing death and its power: "Death should not be understood as an end, as we might think, but as a purpose, as a transformation, as a transfiguration, death taken by Jesus, lived by Him, transfigured through Him. Whereas Adam transfigured love, the sacrifice to the Father and the world through death, Christ, on the Cross and in the grave transforms death into sacrifice - a state of sacrifice, of love, which is the truth of existence - and further transfigures it into love,"22. For those who have wasted their life in passions, death appears to be an end, because they need to separate from their sinful life which generated so much pleasure for them. The end of life and the imminence of death urge man to reflect, make him realize that he is a limited creature. Believing he is free, man enclosed himself in selfishness and passions, but once he becomes aware of death, he comes out of this state and steps towards God. Father Galeriu drew attention to man's temptation to consider himself independent and to reflect on death as a punishment for sin, but also an end of sin.

\section{CONCLUSIONS}

The speeches of Father Professor Constantin Galeriu had a major impact on the believers who listened to them, because he knew the soul and needs of every person, and his words were intended to heal the soul of those in pain. By preaching in a times that is not so remote in the past, his voice still echoes in the ears of many believers who listened to him, even if only once. Although his speech would often last for one hour, the audience did not

${ }^{20}$ Pr. Constantin Galeriu, „Predică la Duminica a XX-a după Rusalii” (Sermon on the $20^{\text {th }}$ Sunday after Pentecost),

http://www.impantokratoros.gr/fiul-vaduvei.ro.aspx, 12. 06. 2017.

$\frac{21}{21}$ Pr. Constantin Galeriu, „Predică la Duminica a XII-a după Rusalii” (Sermon on the $12^{\text {th }}$ Sunday after Pentecost), în 10 predici de părintele..., p. 102.

${ }^{22}$ Pr. Constantin Galeriu, „Predică la Duminica Pogorârii Sfântului Duh” (Sermon on the Sunday of the Descent of the Holy Spirit), în 10 predici de părintele Galeriu..., p. 70. 
show signs of being tired. With well chosen words, in easily comprehensible terms, with explanations that removed any lack of clarity, he would lead his believers towards a full understanding of the truth.

The sermon opened the path to a dialogue for those present. Although, at first sight, the sermon seemed to be a mere monologue that served a teaching purpose, "the interaction of homiletic nature shows perceptive manifestations similar to those of conversation" 23 . From the altar, Father Galeriu related to each believer, because his love embraced all those present, connecting them to the sermon, but especially to the preacher, who uttered his words more with the soul than with the tongue, and this was owed to the fact that "the word must be celebrated so that it will be truly heard" 24 . He addressed the crowd, but each person felt the word as being addressed to him or her personally. The sermon thus became the most appropriate means of conversing with the believers, because it was comforting even when it was harsh. The philosopher Petre Țuțea, noting this gift, said: "Father Galeriu connects you to God when he speaks. Compared to him, all the other priests seem not to preach but to simply utter syllables...."25.

What made the Father's preach really special was the natural way in which he uttered it, the attention he paid to his statements, the clarity of his words, the contents elaborated with such care and thoroughly documented. The speeches were addressed to all believers, because he manifested his love equally. The universal nature and the truth expressed in the Father's sermons originate in the teachings of the Holy Scripture which preach God as the One and Only. The importance of the word of the Gospel is showed in the contents of the sermons not only through the impressive number of occurrences of biblical quotations, but also through the method in which it is construed, so characteristic of the Holy Fathers of the Church. The knowledge of these two sources of theology made the dialogue with other subjects possible, subjects which although sought the truth never came to know it. The holistic view of Father Galeriu identified in the sermon made it possible for the Christians to explain and understand these connections. The various themes approached in the contents of the sermons, always up to date, had a teaching and moralizing role, because believers had the possibility to gain new information, but at the same time they were given the possibility to reflect on their own spiritual state. By understanding the nature and causes of the appearance of the sin, Father Galeriu warns the believers about the manner in which man allows the devil to seduce him, believing that in this way he earns his freedom and dignity. The sermons of the Father have this role of making man aware of sin, making him commit it no more and, helped by God's grace, choose virtue.

These characteristics of the sermons entitle us to assert that Father Galeriu was not only a priest endowed with oratorical energy, but also a scholar of his time, who understood the importance of the contents of a speech, especially in a world of uncertainty and ignorance. The valorization of the teachings comprised in the sermons becomes a necessary undertaking, especially when their message was a contemporary one, related to the evolution of society and of the whole world.

\footnotetext{
${ }^{23}$ Marius Ciobotă, Stilistica predicii, Ed. Spandugino, Bucharest, 2016, p. 100.

${ }^{24}$ John Breck, Sfânta Scriptură în Tradiția Bisericii, trad. de Ioana Tămăian, Ed. Patmos, Cluj-Napoca, 2008, p. 28.

${ }^{25} \mathrm{http}: / /$ www.ceruldinnoi.ro/pages/Constantin_Galeriu.htm, 12. 06. 2017.
} 


\section{BIBLIOGRAPHY:}

[1] Beldiman, pr. Nicuşor, "The Homiletic Activity of Father Prof. Constantin Galeriu (Ph.D.)" in Teologia, 1 (2018).

[2] Breck, John, Sfânta Scriptură în Tradiția Bisericii, trad. de Ioana Tămăian, Ed. Patmos, ClujNapoca, 2008.

[3] Ciobotă, Marius, Stilistica predicii, Ed. Spandugino, Bucharest, 2016.

[4] Galeriu, pr. Constantin, „Predică la Duminica a VI-a după Rusalii” (Sermon on the $6^{\text {th }}$ Sunday after Pentecost),http://www.crestinortodox.ro/predici/predici-duminica/vindecareaslabanogului-capernaum-96267.html, 12.06. 2017.

[5] Galeriu, pr. Constantin, „Predică la Duminica a VIII-a după Rusalii” (Sermon on the $8^{\text {th }}$ Sunday after Pentecost), http://vremurivechisinoi.blogspot.ro/2013/08/predica-la-duminicaviii-dupa-rusalii.html, 12. 06. 2017.

[6] Galeriu, pr. Constantin, „Predică la Duminica a X-a după Rusalii” (Sermon on the $10^{\text {th }}$ Sunday after Pentecost), http://www.crestinortodox.ro/sarbatori/duminica-10-duparusalii/vindecarea-lunaticului-96535.html, 12. 06. 2017.

[7] Galeriu, pr. Constantin, „Predică la Duminica a XII-a după Rusalii” (Sermon on the $12^{\text {th }}$ Sunday after Pentecost), în 10 predici de părintele Galeriu la 10 ani de la mutarea sa la cer (10 sermons by Father Galeriu,marking 10 years from his passing), Ed. Lumea Credinţei, Bucharest, 2013.

[8] Galeriu, pr. Constantin, „Predică la Duminica a XII-a după Rusalii” (Sermon on the $12^{\text {th }}$ Sunday after Pentecost), în 10 predici de părintele...

[9] Galeriu, pr. Constantin, „Predică la Duminica a XIX-a după Rusalii” (Semon on the $19^{\text {th }}$ Sunday after Pentecost), http://www.crestinortodox.ro/sarbatori/duminica-19-duparusalii/predica-pe-munte-iubirea-vrajmasilor-96932.html, 12.06.2017.

[10] Galeriu, pr. Constantin, „Predică la Duminica a XX-a după Rusalii” (Sermon on the $20^{\text {th }}$ Sunday afterPentecost), http://www.impantokratoros.gr/fiul-vaduvei.ro.aspx, 12. 06. 2017.

[11] Galeriu, pr. Constantin, „Predică la Duminica a XXII-a după Rusalii” (Sermon on the $22^{\text {nd }}$ Sunday after Pentecost), http://www.crestinortodox.ro/sarbatori/duminica-22-duparusalii/bogatul-nemilostiv-saracul-lazar-97225.html,12.06. 2017.

[12] Galeriu, pr. Constantin, „Predică la Duminica a XXIII-a după Rusalii” (Sermon on the $23^{\text {rd }}$ Sunday after Pentecost), http://www.crestinortodox.ro/sarbatori/duminica-23-duparusalii/vindecarea-demonizatului-tinutul-gherghesenilor-97100.html, 12. 06. 2017.

[13] Galeriu, pr. Constantin, „Predică la Duminica a XXVII-a după Rusalii” (Sermon on the $27^{\text {th }}$ Sunday after Pentecost), http://www.crestinortodox.ro/sarbatori/duminica-27-duparusalii/tamaduirea-femeii-garbove-98087.html, 12.06.2017.

[14] Galeriu, pr. Constantin, „Predică la Duminica a XXVIII-a după Rusalii” (Sermon on the 28rd Sunday following Pentecost), Glasul Bisericii [Voice of the Church], 10-12 (1977).

[15] Galeriu, pr. Constantin, „Predică la Duminica după Înălțarea Sfintei Cruci” (Sermon on the Sunday after the Exaltation of the Holy Cross), http://www.crestinortodox.ro/predici/prediciduminica/luarea-crucii-urmarea-hristos-96804.html, 12.06.2017.

[16] Galeriu, pr. Constantin, „Predică la Duminica Pogorârii Sfântului Duh” (Sermon on the Sunday of the Descent of the Holy Spirit), în 10 predici de părintele...

[17]Galeriu, pr. Constantin, „Predică la Duminica Sfântului Apostol Toma” (Sermon on the Sunday of the Holy Apostle Thomas), în 10 predici de părintele...

[18] Galeriu, pr. Constantin, „Sermon on the Sunday of SamaritanWoman”, în 10 predici de părintele...

[19]Gordon, pr. Vasile, Pr. Adrian Ivan, Pr. Nicuşor Beldiman, Homiletics, Ed. Basilica, Bucharest, 2015. 